\title{
Invasive Species in Nepal: Appraisal of Legal Provisions and Institutional Setup
}

\author{
Ajay Karki ${ }^{1}$ and Rajan P. Paudel ${ }^{2}$
}

\begin{abstract}
Invasive species are top threat to biodiversity because of their negative effects on floral and faunal species, food web, on ecosystems and their habitat. Their inherent capability to adjust in wide range of environmental conditions and spread at higher pace with economic activities like travel, trade and tourism have necessitated a concern for their prevention and protection. This has been recognized by Convention on Biodiversity that calls the contracting parties to prevent introduction and control or eradication of invasive species. Nepal as a signatory to this convention has to take essential legal and managerial actions to abide by the convention. This paper reviews some literatures and existing legal documents dealing with the invasive species management. The paper finds out that there is impact of Mikenia micrantha in Chitwan National Park and it may affect the productivity the area. There are legal provisions and institutional setup at National and local level under different acts, regulations and guidelines that influence the introduction, control and eradication of this species. This paper recommends that the full functioning of these provisions and institutional setup is required to manage the invasive species.
\end{abstract}

Key Words: Invasive Species, Mikenia, Management, Institution, Legal

\section{Introduction}

Invasive species are also called synonymously with invasive exotics and exotics which threaten native ecosystems, habitats or species, (CBD, 2008). An invasive species is a species that does not naturally occur in a specific area and whose introduction does or is likely to cause economic or environmental harm or harm to human health and these may be flora as well as fauna. Invasive species are able to adjust to a wide range of environmental conditions and spread in higher pace with economic activities like travel, trade and technology, (MEA, 2005). Ecologically and Silviculturally abrupt introduction of a new species to an area affects the species composition. Therefore invasive species are considered

\footnotetext{
${ }^{1}$ Ajay Karki, Officer, Department of Soil and Watershed Conservation E-mail: clickajay@gmail.com

${ }^{2}$ Rajan P. Paudel, MSc. NOMA Scholar, University of Bergen, Norway E-mail: rajanpoudel093@gmail.com
} 
as second most important threat to biodiversity; next to habitat fragmentation since they are important drivers of ecosystem change and alteration of food webs. Their positive impacts also are taken into consideration; ornamental value, option and existence value are the examples. These sometimes have lightened the controversial statements, whether invasive species are friends or foe, pests or providence and weed or wonder (Rai et al, 2012).

This paper explores the case of Mikenia micrantha invasion in Chitwan National Park (CNP), Nepal; protection and prevention measures that have been applied and should be applied for minimizing the negative impacts.

Mikenia micrantha is a perennial sprawling vine with a wide distribution in Neotropics which extends from Mexico to Arzentina, (Holmes, 1982). In its natural territory, it has no invasive behaviour but in Paleotropical range it is a serious weed with a remarkable growth rate $(8-9 \mathrm{~cm})$ in a day, (Choudhary, 1972), that's why; also called as mile-a-minute weed. Basically, it blocks the light to plant by covering it and retards the growth and competes with plants for nutrients and water and sometimes produces the growth inhibitors (Ye and Xia, 2001). This notorious nature of Mikania has placed it in top 100 lists of the worst invading weeds in the world.

Mikenia has invaded Chitwan National Park where people in its vicinity depend on forest area near them for various resources as NTFPs, fodder, timber and fuel-wood and they have hand to mouth problem. To protect these rights and provide them with source for livelihood they are provided with the role of forest manager to manage the area around the park and near them as buffer zone forest. In this context, they firstly have to understand the ecology of invasive species, dynamics of spread and impacts on local species - to manage the forest and making the management decision on the available legal and institutional basis. Numerous legal steps have been implemented and enacted in Nepal to prevent from new invasion and minimize the impacts at national level. Despite of this provisions, the spread of Invasive species is escalating and there lacks the information on what actually is happening to control and manage it at the national and local level.

This paper aims to empirically find out the impact of invasion of Mikania Species in CNP, existing legal provisions for its protection and prevention and to recognize the institutional set up. Further it will recommend some additional protection and prevention measures to be applied in CNP to minimize impacts from Mikania species.

\section{Conceptual-Theoretical Framework}

Series of conventions, conferences and countless organizations (Investing millions of dollars) have recognized the importance of conserving the diversity in flora and fauna, the habitat that beholds them and the vital goods, processes and services their interaction produces. In the meantime, invasive species along with habitat fragmentation and climate change 
have turn out as an intricate problem for executing the efforts of biodiversity conservation. The Convention on Biodiversity has recognized the importance and impact of invasive species on ecosystems and food web and called the contracting parties to "prevent the introduction of, control or eradicate those species which are threatening ecosystems, habitat and species", Article 8 (h), (Neville, 2001). To give effect to article 8 (h), the IUCN also has developed the guideline for prevention of biodiversity loss caused by invasive and alien species in 2000; which assist to government and management agencies to prevent further losses of biodiversity due to deleterious effects of invasive species. In developed world, the scenario is different than developing countries; they can use cost effective method to control and minimize the impacts of invasive species. And in most of the cases of developed world, forest and natural resource is the thing of the least concern to deal with by general mass of people because they use them just for the purpose of recreation and contentment. In contrast, the developing world people have highest concern with natural resource and a single species may have different roles and uses in different locality based on use pattern and economic dynamics directed by locals. So protection and prevention measures may vary species-wise in different locality and social structure. Hence preventing the invasion by species as first task should exist as the most effective, economical, technologically adoptable, environmentally sound ideas to manage the invasive species. If the infestation is already on site, managers have to focus to prevent it from further spreading because eradication is very expensive and sometimes may not be possible. For the developing countries like Nepal, resource limitation is common so limited resource should be spent in an efficient way on proactive weed management which minimizes existing infestations and prevents the further spreading and new invasion.

\section{Data and Method}

The study area, Chitwan national park is the first national park of Nepal (1973) and granted the status of world heritage site in 1984. It is habitat for more than 700 species of wild fauna (including Rhino, Tiger and Elephant) and more than 3000 species of vegetation. More than $80 \%$ area is covered with dense tropical and subtropical forest and rest is grassland, river and water body. Since few years (Not known the exact date of invasion and medium/source of invasion till now) there is invasion of a weed called Mikania, which has created problem in habitat and food of several wildlife, decreased the dominance and existence of some plant species, and have been moving in a direction to alter the structural and functional composition of species.

This paper can be considered as a groping task for invasive species protection and prevention in CNP; to define the real current scenario, its effectiveness and inadequacies. For this, national acts, laws, regulations, agreement and directives were reviewed and simple review on international provision related to protection and prevention from invasive species was made. 


\section{Results and Discussions}

As a signatory on CBD; Nepal has committed to protect and prevent from the invasive species and to minimize the impacts and spreading. Quite a few legal and institutional provisions have been enacted by Nepal for meeting this above mentioned aim. Despite all the odds, Mikania has steadily been engulfing the vast expanse of CNP, creating chaos and creating an extremely difficult condition for the survival of flora and fauna. And most importantly the extent of area being invaded by this noxious weed is increasing day by day. So, this paper has tried to present all the concerned aspects of the invasion by this weed in the following sub headings.

\section{Invasion of Mikania}

About twenty percent habitat of National park in southern belt is covered with this species, which accounts for $50 \%$ of the rhinoceros habitat. It has severely decreased the food of rhinoceros and other herbivores Sapkota (2009) have reported that they have started to feed little bit on Mikania however the species has been used just as an emergency food. Bird's nesting place is covered and they have started to migrate in other suitable habitats. Literature shows that; the species has very low invasion in area having very low forest cover and high forest cover. It was found with higher invasion in the area with crown coverage 20-85\% (Sapkota 2009 and Pers Comm with park staff). Silvicultural operations like thinning, pruning and regular canopy opening works were found to be creating the suitable environment for spreading of the weed. Mean annual increment and biomass of tree and shrub species in buffer zone community forest area was found to be decreased (Pers. comm. with inventory officer) resulting in decrease of whole productivity of the system. In the invasion area, it blocks the light fully resulting in limited undergrowth. Since no herbs grow in the area, the water holding capacity, permeability and infiltration capacity of the soil is found lower than the invasion free area.

\section{International commitment}

Nepal is signatory for CBD, and has developed the National biodiversity strategy and national biodiversity implementation plan; where it has opened the door for making the rules and site specific plan to conserve biodiversity. Secondly, Nepal is member country of CITIES; so there is strict law to export- import the plants and animals enlisted in appendices of CITES. For this purpose both managerial and scientific units are established to strictly implement the law... Thirdly; global organizations like IUCN and WWF are working for protection and prevention from invasive species in CNP, implementing various projects from grass root level to park level.

\section{Legal provisions}

On the legal front, Government of Nepal has arranged many undertakings to create conducive working environment for protecting and preventing the spread of invasive species. Firstly; there is forest act 1995, which has enlisted some species as banned to 
export and import without taking sanction from government. This act also has enlisted some species as protected, for them special management plans are implemented and any harmful activities regarding sustainability and existence to them are highly prohibited. For example, while introducing the exotics; studies are made whether the exotic creates negative impacts on native species or not. And after introduction, if some exotic species inhibit on ecological aspects of these species, the exotic species might be removed from the area. Secondly; there is National Park and Wildlife Conservation Act 1973, which does not speak more about exotics and invasive species but it has converged the focus to maintain the in situ environment to conserve biodiversity by establishing various protected areas and maintaining the ecological equilibrium.

The most important legal instrument in support of protection and prevention from invasive species is 'Plant Protection Act 2007 and Plant Protection Rules 2010'. It has a provision to form a committee at National level to provide comments and suggestions for government on policies of plant and plant product quarantine. According to this act, an entry permit has to be earned if anybody wishes to import plants, plant products, biological control agents, beneficial organisms or means of growing plants such as soil, moss and pit. The government can anytime restrict the import of any specimen belonging to any species without prior notice. There is a provision, which requires obtaining Phyto-sanitary certificate while making export and re-export. If any person or anybody intends to carry any consignments of plants and plant products or other articles, in -transit to another country via the route of Nepal, such person should obtain carriage consignment permit earlier. For the purpose of making inspection of plants, plant products, biological control agents, beneficial organisms or other articles, the government may designate any employee who possesses the qualifications as prescribed, as inspectors to inspect anywhere and anytime. There is provision of penalties up to 500.00 Euro, if anybody makes an offence against the act (Plant protection act, 2007 and rules, 2010).

\section{Institutional set up}

There is a national level organization in the headship of secretary of ministry of Agriculture; which has power to make analysis and determine regulated pests, controlled pests, quarantine pests, invasive pests and delineate any area as quarantine pest affected area,. This organization has full authority to inspect, test, destroy and seize any plants, animals, plant-animal products, and biological control agents if found against the act by mobilizing police and security forces and with the help of inspector (designated by act) and any government agencies. There are 15 quarantine check points in Nepal, including plant quarantine check posts and sub posts. Besides this, different NGOs and INGOs (NTNC, WWF, IUCN including) are actively allocating research funds to make intensive research to understand, manage and prevent further spreading of the Mikania in Chitwan

\section{Local build up}

Locally to prevent further spreading of Mikania in CNP, the national park has its own management plan. It purposes implementation of different options for the management of 
Mikania like: physical removal, research on chemical and biological methods of treatment, and collaboration with local people to work in hand in hand. Similarly, programs on awareness for local people in cooperation with NTNC (national NGO) and WWF Nepal have been done and purposed for future as well. Several Mikania removal camps were organized in National park; once the Prime Minister was also involved along with students, locals, politicians, government's officials and security forces, which have highlighted the necessity of management of this weed.

Community forest users have started making bio briquette (Smokeless charcoal) from Mikania; this can be taken as multiple benefiting aspect because, first it helps in management of invasive species and next it produces less carbon and lowers the pressure for fuel-wood in forest.

\section{Conclusions and Recommendations}

Most effective strategy against invasive species is preventing them from ever being introduced; which seems to be cost effective to eliminate environmental, economic and social impacts. Legally and institutionally; the prevention measures seems to be sufficient enough in Nepal. However, what requires is just a strong implementation in an integrated way with involvement of multi stakeholders, and coordination with local people. For this purpose; education and awareness could be the plausible way to begin with. Poor planning, even lack of theoretical markings and research plans in the protection section are evident; these might be due to financial and technological limitations. Being specific to the site and beholding the notion that 'Prevention is always better than cure'; emphasis needs to be given to protect the area which is still intact and is not invaded by the weed. Careful monitoring of high-risk areas in view of extremely important habitat for endangered wildlife should be done and separate plan for the management of invasion area should be developed.

\section{References}

Choudhury, A. K. 1972. Controversial Mikania (climber) a threat to the forests and agriculture. Indian Forester 98:178-18

Convention on Biological Diversity. 2008. Alien species that threaten ecosystems, habitats or species Article 8(h), Convention on Biological Diversity, United Nations.

Holmes, WC. 1982. Revision of the Old World Mikania (Compositae). Botan Jahres Beitr Systematik 103-211-246

Millennium Ecosystem Assessment. 2005. Ecosystem and human well-beings. Washington, DC: Island Press., pp. 137.

Neville, L. 2001. Global Invasive Species Program (GISP) Update. Aliens 13: 3-6.

Plant protection Act. 2007. Government of Nepal. 
Plant Protection Rule. 2010. Government of Nepal.

Rai, R. K., Scarborough, H., Subedi, N. and Lamichhane, B. 2012. Invasive plants - Do they devastateor diversify rural livelihoods? Rural farmers' perception of three invasive plants in Nepal.Journal for Nature Conservation (2012), doi:10.1016/j.jnc.2012.01.003

Sapkota, L. 2009. Ecology and management issues of Mikania micrantha in Chitwan Naitonal Park, Nepal. Banko Janakari, Kathmandu Vol 17 No 2 pp 27-39.

Ye, W. H. and Xia, Z. 2001. The plant killer-Mikania Micrantha in South China. Aliens 13: 7. 